\title{
Memória e História em livros didáticos de História: o PNLD em perspectiva
}

\section{Memory and History in History schoolbooks: PNLD in perspective}

\author{
Fabiana Rodrigues de Almeida ${ }^{1}$ \\ Sonia Regina Miranda ${ }^{2}$
}

\begin{abstract}
RESUMO
História e Memória, ainda que possam ser tomadas como categorias conceituais intrinsecamente vinculadas, dizem respeito a processos e dimensões da cultura com distinções e especificidades epistemológicas importantes, teorizadas em seus aspectos distintivo e contraditório, prioritariamente a partir da divulgação do clássico de Pierre Nora (1997). Ambas são componentes importantes do saber histórico escolar e ambas possuem lugar na matriz disciplinar da História, desde o processo de construção das bases de seu código disciplinar, para utilizarmos a expressão cunhada por Raimundo Cuesta Fernandes (1998). Contudo, muitas vezes tais distinções são obscurecidas em face de uma tentativa de homogeneização epistemológica que pode provocar implicações importantes para a compreensão do ensino de História. O objetivo desse artigo é apresentar os resultados de uma pesquisa desenvolvida entre os anos 2009-2012 que - avaliando a totalidade das obras aprovadas pelo Programa Nacional do Livro Didático (PNLD) 2011 para a disciplina História e, portanto, partindo de um corpus documental representativo daquilo que circula em todo o território nacional, sob a chancela do Estado brasileiro - buscou cartografar tanto a presença quanto a indiferenciação desses campos nos livros didáticos brasileiros.
\end{abstract}

Palavras-chave: ensino de História; História; memória; livros didáticos; PNLD.

${ }^{1}$ Mestre em Educação pelo Programa de Pós-Graduação em Educação da Universidade Federal de Juiz de Fora, Brasil. E-mail: fahistojf@yahoo.com.br

${ }^{2}$ Doutora em Educação pela Universidade Estadual de Campinas (UNICAMP). Professora da área de Teoria e Metodologia do Ensino de História e do Programa de Pós-Graduação em Educação da Universidade Federal de Juiz de Fora (UFJF), Brasil. E-mail:sonia.miranda@ufjf.edu.br 


\begin{abstract}
Although they may be taken as conceptual categories intrinsically linked, History and Memory relate to processes and dimensions of culture with important epistemological distinctions and specificities, theorized in their distinctive and contradictory aspects, primarily since the release of the classic by Pierre Nora (1997). Both of them are important components of the scholar historical knowledge and the two of them have a place in the disciplinary matrix of History, from the process of constructing its basis for disciplinary code, using the expression coined by Raimundo Cuesta Fernandes (1998). However, such distinctions are often blurred in the face of an attempt of epistemological homogenization which can cause important implications for the comprehension of History teaching. The aim of this paper is to present the results of a survey conducted between 2009-2012 - evaluating the totality of works approved by the National Program of Schoolbooks (PNLD - 2011) for the discipline of History and therefore starting from a representative documental corpus concerning what circulates throughout the national territory, under the auspices of the Brazilian State -, seeking to map both the presence and the indifferentiation of those fields in Brazilian schoolbooks.
\end{abstract}

Keywords: History teaching; History; Memory; schoolbooks; PNLD.

\title{
Memória e contemporaneidade
}

Inúmeros autores têm nos incitado a pensar sobre a presença da Memória como um fenômeno político e social central do contexto histórico em que vivemos na contemporaneidade. Paolo Jedlowski (2010), por exemplo, nos convida a uma reflexão pormenorizada acerca das novas formas de experiência na contemporaneidade, compreendendo o conceito de experiência a partir de uma releitura da obra benjaminiana para além da ideia de crise das tradições, trazendo à tona as vinculações éticas entre o tema da Memória e as novas modalidades de construção de projetos de identidade, nos quais a Memória projeta-se como força propulsora para a construção de sentidos de continuidade da vida. Paul Ricoeur (2008) nos conduz, em sua obra monumental, à compreensão da Memória em sua fenomenologia, por meio de uma reflexão sobre seus excessos, abusos, silenciamentos, seleções e esquecimento e, especialmente, no perdão como uma ação política no presente, perante o mundo e a sociedade. $\mathrm{O}$ efeito de sua interpretação nos conduz a compreender que saber não é um verbo intransitivo. Sabe-se algo, de alguma forma, e, portanto, adquire-se consciência de todas as 
formas de saber por meio de nossa capacidade de lembrar e por nossas atitudes de esquecimento. Andreas Huyssen (2011), na esteira dos teóricos da Escola de Frankfurt, vem também, há alguns anos, nos convidando em diferentes contextos acadêmicos e produções a refletir sobre os efeitos de uma Memória traumática no mundo e sobre as implicações da Memória na cultura de massas e nas cidades, revisitando sua presença na arte, na literatura e nas mídias e dimensionando os efeitos sociais dessa nova mercadoria. Beatriz Sarlo (2005a, 2005b, 2009), em inúmeros textos construídos também sob forte inspiração benjaminiana, tem nos chamado atenção para esse fenômeno na América Latina. Não só os efeitos de uma memória traumática se fazem sentir na relação com a vida política, mas também uma "cultura da Memória" imbrica-se, fortemente, com cenas da vida cotidiana na pluralidade das cidades existente dentro de cada cidade. Nessas cidades, a multiplicidade de possibilidades de narração nos permite encontrar novas miradas para outros sujeitos e outras Memórias, para além daquelas que nos foi possível aprender por meio dos discursos oficiais.

Enfim, poderíamos seguir indicando um grande conjunto de autores que, há mais de duas décadas, vêm se dedicando à investigação dessa temática nos campos da História, da Sociologia, da Psicologia, o que revela, portanto, o crescimento dessa preocupação e a necessidade de se revisitar sempre o que se encontra por detrás dos riscos e potencialidades das operações de Memória. De certo modo, é como se novos contornos culturais e políticos fossem dados àquilo que ainda nos anos 40 do século passado fazia com que George Orwell (1979) nos advertisse para o fato de que "quem controla o passado controla o futuro e quem controla o presente controla o passado". Ou seja, a Memória segue sendo um tema central ao entendimento da sociedade e da política.

Para além do espaço de reflexão acadêmica, a Memória está entranhada por toda parte em nossa vida cotidiana, em múltiplas manifestações. Biografias se convertem em best-sellers por todo o mundo, souvenirs de objetos ou obras de arte produzidos com base na lógica da reprodutibilidade técnica, tal como descrita por Walter Benjamin (1987), vêm homogeneizando hábitos e gestos nas práticas de turismo em todo o mundo. Lembrancinhas e presentinhos para demarcar datas especiais se converteram em mercadorias padronizadas. Ao abrir nossas caixas de e-mails recebemos, diariamente, inúmeras propagandas voltadas para ofertas de revelação de fotos, filmagens exclusivas para aniversários ou casamentos, CDs personalizados com músicas que "marcaram época" e digitalização de fitas VHS em DVD. Cotidianamente, portanto, damo-nos conta de que o consumo da Memória tem se convertido em uma nova mercadoria na contemporaneidade.

Esse fascínio pela Memória, que Andreas Huyssen (2000) denominou "sedução pela Memória", revela um movimento contemporâneo nas sociedades 
ocidentais de interesse pelo registro e pela preservação das lembranças. Segundo Huyssen, essa prática está relacionada aos processos de aceleração do tempo e da História a partir da Segunda Guerra Mundial. Ou seja, podemos dizer que, na passagem do século XX ao XXI, nossa forma de se relacionar com o tempo mudou significativamente. Essa mudança está vinculada ao declínio da visão teleológica da História, na qual o futuro se abria a caminhos previsíveis. Dentro desse "controle" linear, era possível falar em uma História universal e em um tempo cronologicamente instrumentalizado. Posteriormente, com as experiências traumáticas das grandes guerras e crises econômicas mundiais devastadoras, o futuro se abriu ao devir, o que transformou a nossa própria forma de compreender e teorizar o tempo, especialmente depois dos impactos provocados pelas releituras desenvolvidas por Reinhart Koselleck (2001) acerca dos estratos do tempo.

Hoje as projeções de futuro estão fortemente vinculadas a um desejo de Memória e resvalam numa produção excessiva do que Nora (1993) chamou lugares de memórias. Diante da permanente possibilidade de esquecimento disseminada em uma sociedade que produz, diariamente, montanhas de informações, somos impelidos a produzir cada vez mais recursos de Memória. Por essas razões, a Memória agregou na contemporaneidade funções e valores plurais que se constituem como grande questão socialmente posta na atualidade.

São frequentes os movimentos de determinados grupos sociais mobilizando discursos de Memória, antes esquecidos ou silenciados no tempo, a fim de reivindicar seu lugar no mundo como sujeitos na História. Nessa direção, cresce a atenção aos deveres de Memória, interpostos por lutas particulares, como narrativa fundamental para explicação do mundo, não mais assentados na interpretação histórica que selecionam, e em muitos casos excluem, mas na própria formação da consciência de si na História. Exemplos bastante elucidativos, no Brasil, sobre a força desse movimento de embate da Memória na contemporaneidade resvalam nas lutas do movimento negro que, antes, tinha sua identidade nacional ancorada na noção de ausência de conflito étnico-racial e, hoje, reivindica a consciência de uma identidade negra a partir da reinterpretação historiográfica do seu passado na História brasileira. Em resposta a essas reivindicações, o governo propõe políticas afirmativas, como o estabelecimento de cotas para afrodescendentes em universidades públicas e a introdução da Lei 11.645, que torna obrigatório o estudo da história e da cultura afro-brasileira e indígena, fatos que não ocorrem, contudo, nem de modo harmônico e tampouco generalizado. Um exemplo contemporâneo dotado de grande complexidade a esse respeito pode ser observado por meio do tratamento reducionista que vem sendo dado à obra de Monteiro Lobato e a restrição à sua distribuição às escolas brasileiras quando se vive, justamente, um contexto de democratização da 
sociedade. Assim, ao se "julgar" obra e autor como racistas, descontextualiza-se a obra em sua historicidade e procede-se a uma censura nos moldes de qualquer tipo de censura cultural e ideológica outrora já praticada em tempos de exceção, nesse caso, com uma âncora fortemente anacrônica, em nome de um dever de Memória.

Outro movimento que revela o apelo à Memória, em nosso país, e que tem provocado grandes debates envolvendo políticos, estudantes, artistas, assim como amigos e familiares que tiveram pessoas próximas vítimas da ditadura militar, refere-se à instituição da "Comissão da Verdade" que, embora não vise penalizar antigos infratores, assume o objetivo de tornar pública uma parte da História do Brasil que não se deseja silenciar ou esquecer. Esse movimento não se restringe ao nosso país. São muitos os casos, em diversas partes do mundo, de buscas de ressignificação do passado por movimentos sociais, como se tem observado por meio de embates e disputas simbólicas entre as minorias étnicas na Europa, como os conflitos do povo basco na Espanha; a afirmação da língua catalã na Catalunha após uma longa história de censura e perseguições; a força do IRA na Grã-Bretanha e as fragmentações de poder no leste europeu; na África, como as disputas na região de Darfur; na Ásia, com os conflitos na região da Caxemira e no Sri Lanka; e na América, evidencia-se o movimento separatista do Quebec. Sem contar aqueles movimentos de grande repercussão ao redor do mundo, em que a mobilização da Memória serve como elemento de manutenção da chama dos conflitos entre árabes e judeus, bem como os constantes movimentos de usos do passado em torno dos traumas do nazifascismo. Enfim, são apenas alguns dos exemplos da relevância social, política e acadêmica que o campo temático da Memória assume na atualidade.

No contraponto dessa dimensão política, que não pode ser desconsiderada, Paul Ricoeur nos mostrou que Memória é vida e atravessa a existência humana conferindo-lhe significação, sentido, afetividade. Afinal, é intrínseca à condição humana a busca de formas de localização no tempo e no espaço, sobretudo como forma de nos entendermos enquanto sujeitos dentro de um grupo específico e em relação a outros grupos em diferentes temporalidades. Por intermédio das práticas de Memória se fortalecem as condições necessárias à formação de uma orientação básica no tempo. Essa habilidade está vinculada a nossa capacidade de estabelecer diálogos com o passado e com o futuro, sendo o tempo presente o lugar de construção dessa inteligibilidade. Por meio das operações de Memória, com toda sua dinâmica de lembranças e esquecimentos, se torna possível avançar num tempo anterior ao de nossa existência e projetar ações para o futuro.

Dessa forma, quando falamos dos usos e abusos da Memória no mundo contemporâneo, faz sentido pensar nas considerações de Sonia Meneses Silva que, inspirando-se em Pierre Nora, nos propõe que "a memória produzida hoje 
é bem diferente da memória gestual, intuitiva, transmitida entre silêncios e 'saberes reflexos', ela é, sobretudo, memória vivida como um 'dever e não mais espontânea"' (SILVA, 2009, p. 234).

A escola, e especialmente o ensino de História como campo de saber onde tais questões normalmente são atribuídas como de sua responsabilidade, é profundamente afetada pelos efeitos desse debate. Por um lado, a escola convive com uma profusão de narrativas produzidas no seu entorno, por parte de alunos, professores e comunidade, em diálogo com aquelas que são trazidas, com muita força, para o interior da sala de aula e revelam formas de explicar o mundo através daquilo que faz sentido para os sujeitos. Por outro lado, a escola convive com a reprodução de práticas de Memória comuns à sociedade (JEDLOWSKI, 2010) e que conduzem à permanência, no senso comum, de uma dada lógica de representação do passado. Há, ainda, os mecanismos de reatualização de costumes ou comemorações de eventos que reforçam os laços de pertencimento no interior de um grupo ou sociedade, o que, muitas vezes, é desencadeado pela própria escola. Enfim, a escola é um lugar potencialmente atravessado por Memórias.

Assim, o desafio interposto atualmente ao ensino de História refere-se aos próprios desafios inseridos pela Memória no tempo presente, uma Memória que reivindica lugares, que aquece o mercado de consumo, que elege o que deve ou não ser preservado, que luta contra as avalanches de esquecimento. Enfim, a educação para a compreensão da História passa a ter em si também o desafio de lidar com os procedimentos derivados das operações de Memória que estão na ordem do dia dos sujeitos e que interferem diretamente na interpretação que esses fazem acerca das experiências passadas, orientando sua ação no presente e, sobretudo, sua projeção de futuro. Nesse sentido, as práticas de Memória se fortalecem como condição necessária à formação da consciência histórica.

Pensar, então, a Memória em suas operações de lembranças e esquecimento consiste em pensar ações inteligíveis que fazem parte do cotidiano dos alunos e orientam seu estar no mundo e que, por essa razão, dizem respeito diretamente ao que pode ser mobilizado como porta de acesso ao saber histórico e ao conhecimento das mudanças e permanências no tempo. O livro didático de História, nesse contexto, assume lugar de grande relevância no ensino de História em nosso país, já que o Programa Nacional do Livro Didático (PNLD) situa-se entre os maiores programas de distribuição de livros didáticos do mundo, proporcionando, assim, profundos impactos no sistema de ensino e no mercado editorial brasileiro. Por este motivo, coube-nos pensar: como a distinção entre os campos de saber da Memória e da História é evidenciada e teorizada pelos autores no interior dos livros didáticos de História?

Porém, a relação entre História e Memória enquanto campos de saber específicos é complexa e contraditória no próprio território do historiador, o que 
resvala na forma pela qual a relação entre tais campos se estabelece no âmbito educacional. Ambos possuem relação direta com o ensino de História pela especificidade de procedimentos dos quais cada um lança mão para construção de narrativas acerca do pretérito. Por isso, julgamos necessário pensar as duas dimensões de saber como campos que ora convergem e, sobretudo, ora dissonam em suas particularidades, problematizando-as enquanto objetos singulares e pertinentes ao campo do ensino. As distinções entre os campos assumem peso fundamental em nossa análise por considerarmos que as operações próprias de cada uma dessas dimensões repercutem em ações pedagógicas diferentes no ensino de História e, por essa razão, consideramos essencial explorar as especificidades de cada campo, saindo do senso comum de homogeneidade epistemológica entre ambos, a fim de auxiliar no engendramento de práticas reflexivas por parte do professor.

\section{O saber histórico escolar, entre a História e a Memória}

Ainda que a obra de Nora (1997) apresente uma proposta clara de distinção de tais campos conceituais e os debates contemporâneos acerca dos usos e abusos do passado tenham trazido contribuições importantes para se pensar nos abusos da Memória, quando pensamos o ensino de História verifica-se, ainda, uma tendência de subdimensionamento de tal reflexão. Quando muito, fortalece-se a ideia de uma potencialidade crítica do conhecimento histórico em seus procedimentos e métodos como âncora sobre a qual se deve processar esse ensino, subdimensionando-se o sentido das operações da Memória. Esse movimento pode não só trazer sérias repercussões para o aprofundamento reflexivo acerca do ensino de História e para a construção da autonomia intelectual do professor, especialmente no tocante aos usos e apropriações do livro didático em sala de aula, como pode obscurecer a potencialidade da Memória, tomada como dimensão social e cultural central ao processo de produção e apropriação de saberes significativos por parte dos estudantes.

Então, se História e Memória não são sinônimos, o que é "História" e o que é "Memória"? O que as difere e o que as aproxima? Uma prescinde da outra para existir? Ivo Mattozzi nos fala que "na origem da historiografia ocidental se encontra a vontade de usar a Memória para fazer dela uma outra coisa que tomou o nome de História" (2008, p. 10). Entretanto, lembrar o passado e escrever sobre ele não são a mesma coisa. Ainda assim, após séculos de discussões, a historiografia nos apresenta que os debates em torno da Mnemósine e Clio são ambíguos, fluidos e estão longe de serem resolvidos. 
Essa confusão entre os dois campos de saber acontece quando esquecemos que a Memória é um processo profundamente ligado à construção de sentido; ou, como o próprio Manuel Salgado Guimarães diz, a Memória nos fala de “certezas (do sagrado e imutável)" (2009, p. 43) ao passo que a História não passa pela identificação, ela se constitui enquanto operações destinadas à análise do passado, aberta às dúvidas e críticas.

Se para a antiga noção de História como sinônimo de Memória o passado era entendido como continuidade, passível de ser rememorado, e por isso seu resgate seria suficiente para formar as identidades nacionais, hoje a noção de História dissociada da noção de Memória entende o passado como algo impossível de se recuperar em sua totalidade. O que se tem dele são vestígios, lacunas e silêncios que provam sua descontinuidade no tempo. Logo, a concepção de passado produzido pela História não passa de representações incompletas, pontuais e parciais de um historiador sobre seus indícios selecionados.

Algumas pesquisas recentes no campo do ensino de História têm explorado a importância da discussão da Memória para a formação dos alunos quanto a sua compreensão de tempo e espaço, assim como sua localização e construção de sentido. Essa perspectiva, contudo, requer um novo olhar para a Memória, não mais como espelho fiel do passado pronto para ser recuperado, mas como objeto de um tempo presente.

Dentre todas essas transformações no campo da Memória é importante chamar atenção para o novo significado do movimento de guarda. Nora (1993) afirma que a Memória se tornou, na contemporaneidade, "historicizada", ou seja, tudo que ganhou status de Memória não mais se constitui como tal, pois sua legitimação não se dá de forma espontânea. Os lugares de Memória são exemplos que Nora utiliza para afirmar esse paradoxo que a Memória atualmente vive. Por exemplo, a multiplicação de museus e discursos patrimoniais institui que cabe aos grupos sociais preservar tais Memórias ali selecionadas, sem que isso implique uma vontade genuína. Dessa forma, a Memória, quando é historicizada, deixa de ser prática e torna-se dever social, o dever de nada esquecer!

Pelo contrário, Nora afirma que Memória é vida, cheia de revitalizações e identificações através de seu jogo de lembranças e esquecimentos

[...] porque é afetiva e mágica, a memória não se acomoda a detalhes que a confortam, ela se alimenta de lembranças vagas, telescópicas, globais ou flutuantes, particulares ou simbólicas, sensível a todas as transferências, cenas, censuras ou projeções (NORA, 1993, p. 9). 
Ao passo que a História nada mais é do que uma representação imperfeita, porque parcial, do passado. Constitui-se como operação crítica da Memória, cheia de intencionalidades e distâncias, já que seu encontro com o passado é mediado por rastros, vestígios e silêncios. Nora sintetiza muito bem a especificidade de cada campo de saber quando diz que "a memória é um absoluto e a história só conhece o relativo" (NORA, 1993, p. 9).

Contudo, a oposição engendrada por Nora também nos apresenta desafios delicados. A Memória, ao se projetar como saber específico e, portanto, distinto do campo da História, perdeu significativamente seu espaço discursivo no interior do saber escolar. É como se coubesse à História a tarefa de destituir a Memória do seu lugar de certezas, restringindo a aula de História a um discurso historiográfico desprovido de bases que o tornem plausível, muitas vezes, para o sujeito. O desafio hoje interposto ao ensino de História consiste, portanto, em aprofundar os caminhos de diálogos possíveis entre os dois campos de saber a fim de promover uma educação que evidencie as operações de memória como elementos potentes para a formação do pensamento histórico.

Isso não significa dizer que, embora sejam campos de saberes distintos, História e Memória não tecem diálogos necessários, pelo contrário. A História lança mão da Memória como fonte - e a partir dela desenvolve suas operações de análise do passado - e como fenômeno histórico - que envolve a crítica dos processos de seleção da Memória (BURKE, 2000). Segundo Peter Burke, "as memórias são maleáveis, e é necessário compreender como são concretizadas, e por quem, assim como os limites dessa maleabilidade" (2000, p. 73). Dessa maneira, é importante ressaltar que a distinção entre os campos facilita a formação de um pensamento crítico dos sujeitos sobre suas tradições e sobre as outras que compõem a sua sociedade. Todavia, a História não prescinde da Memória, e vice-versa. A História é capaz de investigar, através dos indícios, experiências que foram esquecidas no tempo (MIRANDA, 2007), assim como uma Memória pode se tornar legítima com ou sem a crítica da História.

O pensamento histórico, mobilizado pela Memória histórica, é capaz de formar identidade numa perspectiva temporal, até mesmo como forma de conter as mudanças que ameaçam o entendimento do mundo e do futuro. É comum um grupo fortalecer seus laços de identidade para reforçar suas concepções, valores e ideias. Assim, a identidade pode ser considerada uma conquista da consciência histórica, cujo procedimento de criação de sentido se faz através da evocação da Memória na sua relação temporal de experiência do passado à expectativa de futuro.

O saber histórico escolar está sempre fundamentado em uma experiência do tempo específica, cuja construção de sentido se vincula às experiências de cada sujeito ou sociedade, gerando diferentes narrativas acerca do passado. Por 
esse motivo, não faz sentido uma educação que prescinda da reflexão do procedimento histórico na qual as operações envolvendo as práticas de Memórias ocupam lugar de destaque.

O diálogo entre tempos na formação do pensamento histórico pode, e deve, ser estimulado pelas operações de Memória. Através dela é possível criar um ambiente de inteligibilidade do passado para o aluno, pois muitas vezes esse passado é apresentado de forma unívoca e incompreensível, sem qualquer ponto de apoio que ofereça uma ideia de distância quanto a sua realidade presente. Do contrário, quando se parte das Memórias do aluno e do grupo ao qual ele pertence, e em seguida se avança num tempo anterior ao de sua existência, a criança consegue dimensionar esse passado de forma mais consistente. No entanto, esse exercício de entendimento temporal só se torna possível quando as operações de Memória são trabalhadas com clara intencionalidade didática em sala de aula, reconhecendo, como Sonia Miranda (2009), que toda polifonia chega à escola, ainda que nem sempre a mesma se faça visível. Para isso, porém, é desejável perseguir o desafio de se evitar as armadilhas insidiosas da prescrição curricular e avançar em direção àquilo que Ivor Goodson (2007) preconiza como um currículo enquanto narrativa, "baseado na elaboração e na manutenção continuada de uma narrativa de vida ou de identidade" (p. 248).

Assim, quando o saber histórico escolar, mobilizado pela discussão procedimental da História e das operações de Memória, possibilita um novo olhar sobre o passado e sobre a História, ele se torna capaz de conferir ao aluno um lugar de protagonismo imprescindível à construção de empatia histórica. Do contrário, quando essa relação com as práticas de Memória é rompida, ou silenciada, o conhecimento histórico é capaz de afastar o aluno da composição da mesma. Isso significa dizer que o ensino de História constitui-se como campo aberto a todo tipo de reflexão acerca da construção de identidade dos alunos, bem como de todas as outras possíveis histórias.

Se para o ensino de História as dimensões de História e Memória são unidades associadas e imbricadas, por outro lado elas dizem respeito a dimensões conceituais distintas que precisam ser bem compreendidas para que sua exploração didática em sala de aula seja potencializada. Por este motivo, procuramos analisar os livros didáticos em circulação no Brasil, de forma particular aqueles inscritos e aprovados pela avaliação do Programa Nacional do Livro Didático do Ministério da Educação. Para assim compreender, ainda que de forma panorâmica, o lugar que a Memória e suas operações ocupam no saber histórico preconizado por um tipo contemporâneo de mercadoria que se converteu em uma das mais importantes ferramentas de suporte didático e formação de professores: o livro didático. 


\section{Um espelho e algumas miradas: o Programa Nacional do Livro Didático Brasileiro, a História e a Memória}

Embora se observe uma tendência mais recente, no campo investigativo sobre livros didáticos, relativa aos usos e apropriações dos livros por parte de professores, consideramos que a distinção proposta entre dimensões conceituais centrais à operação histórica, e, consequentemente, ao seu ensino, ainda não foi suficientemente tematizada em termos da pesquisa e, por essa razão, reiterar a análise de conteúdo e, consequentemente, do texto didático tende, ainda, a oferecer contribuições significativas para o campo da formação de professores.

Isso significa dizer que não se trata de um conteúdo indiferente ao ensino, passível de subdimensionamento, mas de uma relação epistemológica central, que permite aprofundar a compreensão acerca das aprendizagens escolares e da natureza do saber histórico escolar. Para tanto, nos pautaremos nos resultados auferidos com a análise das coleções de História destinadas ao ensino fundamental que foram inscritas e aprovadas pela avaliação do PNLD 2011.

Os dados que serão apresentados e refletidos aqui compõem um quadro de 16 coleções didáticas de História, do $6^{\circ}$ ao $9^{\circ}$ ano do ensino fundamental, gerando um total de 64 livros analisados. Nesse texto, optamos por apresentar apenas alguns fragmentos daquilo que foi objeto de estudo mais aprofundado na dissertação de mestrado resultante daquela ação avaliativa (ALMEIDA, 2012). Foram retiradas da análise as obras excluídas, de modo a garantir a exigência de sigilo por parte do MEC. Nossa intenção consistiu em lançar sobre elas um olhar de conjunto sobre como a discussão da Memória tem sido enfrentada nas obras didáticas de História. Esse olhar de conjunto sobre as obras - e os riscos derivados dos mecanismos de categorização - é, hoje, um dos principais desafios enfrentados durante a produção do Guia do Livro Didático do PNLD, visto que muitos professores, em todo território nacional, partem apenas desse suporte para escolher seu material didático. Para evidenciar o processo de análise que pautou esta pesquisa e assim propiciar um olhar panorâmico sobre as obras, juntamente com os gráficos que compõem esse artigo, tornou-se necessária a produção de um quadro quantitativo que pudesse revelar as frequências com que os temas da História e da Memória aparecem em cada coleção didática, para que, assim, fosse possível estabelecer uma unidade de significação tanto das regularidades quanto das ausências dessa discussão no livro do aluno e no Manual do Professor.

O quadro de análise consiste, portanto, num levantamento quantitativo das frequências da discussão conceitual e procedimental do campo da História 
presentes no texto base de cada livro. Tomaram-se tais frequências como um indicador plausível acerca das operações de seleção efetivamente praticadas em cada obra. Como o foco desta pesquisa concentra-se, substantivamente, na análise do campo da Memória, para a composição do quadro sua análise se estendeu para além do que é evidenciado no texto base, buscando perceber como essa discussão se configura em toda a coleção. Para isso, ampliou-se o olhar para as atividades, os textos complementares, o Manual do Professor e as indicações bibliográficas constantes de cada volume.

Observando o quadro a seguir, é possível perceber, a partir de um olhar de conjunto, que a definição de História é, em geral, tópica, pouco desenvolvida e, em sua grande maioria, restrita ao livro de $6^{\circ}$ ano. O campo da História, em seu sentido procedimental, na maioria das coleções, é secundarizado, o que abre espaço para a fixação de uma visão de História como narrativa acontecimental e absoluta. Já a Memória, em suas dimensões de epistemologia e potência de aprendizagem, na medida em que permite o estabelecimento de pontes com o universo sensível do aluno, é francamente secundarizada, senão silenciada, em boa parte das coleções, saltando aos olhos o fato de que se verifica uma dissonância entre texto base e exercícios.

Em relação à frequência da temática da Memória nos manuais do professor, é possível dizer que ela se ancora mais em indicações bibliográficas, apoiadas em autores de referência na discussão do campo, que na orientação didática capaz de fortalecer o processo de ensino para educação da Memória.

No primeiro movimento de análise sistemática das obras, partimos do conhecimento e da análise conceitual do que é "História" para cada coleção aprovada. Esse movimento trouxe evidências importantes sobre a concepção de ensino de História que a coleção adota. Claro que essa pergunta isolada não bastaria para considerar ou classificar uma obra como tradicional ou inovadora, mas já traz indicadores interessantes do ponto de vista de valorização do campo e do ofício do historiador. Perguntas como essa nos conduzem ao caráter formativo que está por trás de cada obra: se o que se valoriza é apenas a erudição - não considerando essa "apenas" uma atividade simples ou de menos valor, porém evidencia, na maioria das vezes, uma única perspectiva narrativa - ou se a educação histórica baseia-se em nexos estabelecidos entre o procedimento histórico e o saber escolar de referência. 


\begin{tabular}{|c|c|c|c|c|c|c|}
\hline Coleções & $\begin{array}{l}\text { Quantas } \\
\text { vezes uma } \\
\text { definição } \\
\text { de História } \\
\text { aparece } \\
\text { no texto } \\
\text { base? }\end{array}$ & $\begin{array}{l}\text { Quantas vezes } \\
\text { a temática da } \\
\text { História, em } \\
\text { seu sentido } \\
\text { procedimental, } \\
\text { aparece no } \\
\text { texto base? }\end{array}$ & $\begin{array}{l}\text { Quantas vezes } \\
\text { a temática } \\
\text { da Memória, } \\
\text { em sua } \\
\text { especificidade, } \\
\text { aparece no } \\
\text { texto base? }\end{array}$ & $\begin{array}{l}\text { Quantas vezes } \\
\text { a temática } \\
\text { da Memória } \\
\text { aparece nos } \\
\text { exercícios e } \\
\text { propostas de } \\
\text { atividades para } \\
\text { os alunos? }\end{array}$ & $\begin{array}{l}\text { Quantas vezes } \\
\text { a temática da } \\
\text { Memória aparece } \\
\text { no manual do } \\
\text { professor, em sua } \\
\text { especificidade? }\end{array}$ & $\begin{array}{l}\text { Quantas } \\
\text { vezes o tema } \\
\text { da Memória } \\
\text { aparece em } \\
\text { referências } \\
\text { bibliográficas } \\
\text { para o } \\
\text { professor? }\end{array}$ \\
\hline História & $\begin{array}{l}6^{\circ} .1 \\
7^{\circ} .- \\
8^{\circ} .- \\
9^{\circ} .- \\
\end{array}$ & $\begin{array}{l}6^{\circ} .- \\
7^{\circ} .- \\
8^{\circ} .1 \\
9^{\circ} .- \\
\end{array}$ & $\begin{array}{l}6^{\circ} .- \\
7^{\circ} .- \\
8^{\circ} .- \\
9^{\circ} .-\end{array}$ & $\begin{array}{l}6^{\circ} .1 \\
7^{\circ} .- \\
8^{\circ} .- \\
9^{\circ} .-\end{array}$ & $\begin{array}{l}6^{\circ} .- \\
7^{\circ} .- \\
8^{\circ} .- \\
9^{\circ} .-\end{array}$ & $\begin{array}{l}6^{\circ} .1 \\
7^{\circ} .1 \\
8^{\circ} .- \\
9^{\circ} .-\end{array}$ \\
\hline $\begin{array}{l}\text { História das } \\
\text { cavernas } \\
\text { ao Terceiro } \\
\text { Milênio }\end{array}$ & $\begin{array}{l}6^{\circ} .1 \\
7^{\circ} .- \\
8^{\circ} .- \\
9^{\circ} .-\end{array}$ & $\begin{array}{l}6^{\circ} .3 \\
7^{\circ} .1 \\
8^{\circ} .- \\
9^{\circ} .-\end{array}$ & $\begin{array}{l}6^{\circ} .1 \\
7^{\circ} .- \\
8^{\circ} .- \\
9^{\circ} .-\end{array}$ & $\begin{array}{l}6^{\circ} .6 \\
7^{\circ} .1 \\
8^{\circ} .2 \\
9^{\circ} .2\end{array}$ & $\begin{array}{l}6^{\circ} .3 \\
7^{\mathrm{o}} .- \\
8^{\mathrm{o}} .- \\
9^{\mathrm{o}} .-\end{array}$ & $\begin{array}{l}6^{\circ} .2 \\
7^{\circ} .2 \\
8^{\circ} .2 \\
9^{\circ} .2\end{array}$ \\
\hline $\begin{array}{l}\text { História } \\
\text { e vida } \\
\text { integrada }\end{array}$ & $\begin{array}{l}6^{\circ} .1 \\
7^{\circ} .- \\
8^{\circ} .- \\
9^{\circ} .-\end{array}$ & $\begin{array}{l}6^{\circ} .2 \\
7^{\circ} .- \\
8^{\circ} .- \\
9^{\circ} .-\end{array}$ & $\begin{array}{l}6^{\circ} .- \\
7^{\circ} .- \\
8^{\circ} .- \\
9^{\circ} .-\end{array}$ & $\begin{array}{l}6^{\circ} .3 \\
7^{\circ} .- \\
8^{\circ} .- \\
9^{\circ} .-\end{array}$ & $\begin{array}{l}6^{\circ} .- \\
7^{\circ} .- \\
8^{\circ} .- \\
9^{\circ} .-\end{array}$ & $\begin{array}{l}6^{\circ} .- \\
7^{\circ} .- \\
8^{\circ} .- \\
9^{\circ} .-\end{array}$ \\
\hline $\begin{array}{l}\text { História em } \\
\text { documento }\end{array}$ & $\begin{array}{l}6^{\circ} .1 \\
7^{\circ} .- \\
8^{\circ} .- \\
9^{\circ} .-\end{array}$ & $\begin{array}{l}6^{\circ} .5 \\
7^{\circ} .2 \\
8^{\circ} .2 \\
9^{\circ} .1\end{array}$ & $\begin{array}{l}6^{\circ} .- \\
7^{\circ} .- \\
8^{\circ} .- \\
9^{\circ} .-\end{array}$ & $\begin{array}{l}6^{\circ} .6 \\
7^{\circ} .5 \\
8^{\circ} .4 \\
9^{\circ} .6\end{array}$ & $\begin{array}{l}6^{\circ} .- \\
7^{\circ} .- \\
8^{\circ} .- \\
9^{\circ} .-\end{array}$ & $\begin{array}{l}6^{\circ} .1 \\
7^{\circ} .1 \\
8^{\circ} .1 \\
9^{\circ} .1\end{array}$ \\
\hline $\begin{array}{l}\text { História em } \\
\text { projetos }\end{array}$ & $\begin{array}{l}6^{\circ} .- \\
7^{\circ} .- \\
8^{\circ} .- \\
9^{\circ} .-\end{array}$ & $\begin{array}{l}6^{\circ} .- \\
7^{\circ} .- \\
8^{\circ} .- \\
9^{\circ} .-\end{array}$ & $\begin{array}{l}6^{\circ} .- \\
7^{\circ} .- \\
8^{\circ} .- \\
9^{\circ} .-\end{array}$ & $\begin{array}{l}6^{\circ} .- \\
7^{\circ} .- \\
8^{\circ} .- \\
9^{\circ} .-\end{array}$ & $\begin{array}{l}6^{\circ} .- \\
7^{\circ} .- \\
8^{\circ} .- \\
9^{\circ} .-\end{array}$ & $\begin{array}{l}6^{\circ} .- \\
7^{\circ} .- \\
8^{\circ} .- \\
9^{\circ} .-\end{array}$ \\
\hline $\begin{array}{l}\text { História, } \\
\text { Sociedade e } \\
\text { Cidadania }\end{array}$ & $\begin{array}{l}6^{\circ} .1 \\
7^{\circ} .- \\
8^{\circ} .- \\
9^{\circ} .-\end{array}$ & $\begin{array}{l}6^{\circ} .3 \\
7^{\circ} .1 \\
8^{\circ} .- \\
9^{\circ} .-\end{array}$ & $\begin{array}{l}6^{\circ} .- \\
7^{\circ} .- \\
8^{\circ} .- \\
9^{\circ} .-\end{array}$ & $\begin{array}{l}6^{\circ} .3 \\
7^{\circ} .- \\
8^{\circ} .- \\
9^{\circ} .-\end{array}$ & $\begin{array}{l}6^{\circ} .- \\
7^{\circ} .- \\
8^{\circ} .- \\
9^{\circ} .-\end{array}$ & $\begin{array}{l}6^{\circ} .3 \\
7^{\circ} .- \\
8^{\circ} .- \\
9^{\circ} .-\end{array}$ \\
\hline $\begin{array}{l}\text { História } \\
\text { temática }\end{array}$ & $\begin{array}{l}6^{\circ} .1 \\
7^{\circ} .1 \\
8^{\circ} .- \\
9^{\circ} .-\end{array}$ & $\begin{array}{l}6^{\circ} .7 \\
7^{\circ} .4 \\
8^{\circ} .3 \\
9^{\circ} .4\end{array}$ & $\begin{array}{l}6^{\circ} .5 \\
7^{\circ} .1 \\
8^{\circ} .1 \\
9^{\circ} .-\end{array}$ & $\begin{array}{l}6^{\circ} .15 \\
7^{\circ} .6 \\
8^{\circ} .4 \\
9^{\circ} .4\end{array}$ & $\begin{array}{l}6^{\circ} .3 \\
7^{\circ} .2 \\
8^{\circ} .2 \\
9^{\circ} .1\end{array}$ & $\begin{array}{l}6^{\circ} .4 \\
7^{\circ} .3 \\
8^{\circ} .3 \\
9^{\circ} .2\end{array}$ \\
\hline $\begin{array}{l}\text { Navegando } \\
\text { pela História }\end{array}$ & $\begin{array}{l}6^{\circ} .1 \\
7^{\circ} .1 \\
8^{\circ} .- \\
9^{\circ} .-\end{array}$ & $\begin{array}{l}6^{\circ} .3 \\
7^{\circ} .1 \\
8^{\circ} .- \\
9^{\circ} .-\end{array}$ & $\begin{array}{l}6^{\circ} .- \\
7^{\mathrm{o}} .- \\
8^{\mathrm{o}} .- \\
9^{\mathrm{o}} .-\end{array}$ & $\begin{array}{l}6^{\circ} .2 \\
7^{\circ} .- \\
8^{\circ} .- \\
9^{\circ} .-\end{array}$ & $\begin{array}{l}6^{\circ} .- \\
7^{\mathrm{o}} .- \\
8^{\mathrm{o}} .- \\
9^{\mathrm{o}} .-\end{array}$ & $\begin{array}{l}6^{\circ} .- \\
7^{\circ} .- \\
8^{\text {o. }} .- \\
9^{\text {o. }} .\end{array}$ \\
\hline $\begin{array}{l}\text { Nova - } \\
\text { História } \\
\text { - conceitos } \\
\text { e procedi- } \\
\text { mentos }\end{array}$ & $\begin{array}{l}6^{\circ} .1 \\
7^{\circ} .- \\
8^{\circ} .- \\
9^{\circ} .-\end{array}$ & $\begin{array}{l}6^{\circ} .2 \\
7^{\circ} .- \\
8^{\circ} .1 \\
9^{\circ} .-\end{array}$ & $\begin{array}{l}6^{\circ} .- \\
7^{\circ} .- \\
8^{\circ} .- \\
9^{\circ} .-\end{array}$ & $\begin{array}{l}6^{\circ} .3 \\
7^{\circ} .1 \\
8^{\circ} .- \\
9^{\circ} .-\end{array}$ & $\begin{array}{l}6^{\circ} .1 \\
7^{\circ} .- \\
8^{\circ} .- \\
9^{\circ} .-\end{array}$ & $\begin{array}{l}6^{\circ} .2 \\
7^{\circ} .- \\
8^{\circ} .- \\
9^{\circ} .-\end{array}$ \\
\hline $\begin{array}{l}\text { Para } \\
\text { entender } \\
\text { História }\end{array}$ & $\begin{array}{l}6^{\circ} .1 \\
7^{\circ} .- \\
8^{\circ} .- \\
9^{\circ} .-\end{array}$ & $\begin{array}{l}6^{\circ} .3 \\
7^{\circ} .- \\
8^{\circ} .- \\
9^{\circ} .-\end{array}$ & $\begin{array}{l}6^{\circ} .1 \\
7^{\circ} .- \\
8^{\circ} .- \\
9^{\circ} .-\end{array}$ & $\begin{array}{l}6^{\circ} .3 \\
7^{\circ} .- \\
8^{\circ} .1 \\
9^{\circ} .-\end{array}$ & $\begin{array}{l}6^{\circ} .4 \\
7^{\circ} .- \\
8^{\circ} .- \\
9^{\circ} .-\end{array}$ & $\begin{array}{l}6^{\circ} .1 \\
7^{\circ} .- \\
8^{\circ} .- \\
9^{\circ} .-\end{array}$ \\
\hline $\begin{array}{l}\text { Para viver } \\
\text { juntos - } \\
\text { História }\end{array}$ & $\begin{array}{l}6^{\circ} .1 \\
7^{\circ} .- \\
8^{\circ} .- \\
9^{\circ} .-\end{array}$ & $\begin{array}{l}6^{\circ} .3 \\
7^{\circ} .- \\
8^{\circ} .- \\
9^{\circ} .-\end{array}$ & $\begin{array}{l}6^{\circ} .1 \\
7^{\circ} .- \\
8^{\circ} .- \\
9^{\circ} .-\end{array}$ & $\begin{array}{l}6^{\circ} .3 \\
7^{\circ} .- \\
8^{\circ} .1 \\
9^{\circ} .1\end{array}$ & $\begin{array}{l}6^{\circ} .3 \\
7^{\circ} .- \\
8^{\circ} .- \\
9^{\circ} .1\end{array}$ & $\begin{array}{l}6^{\circ} .1 \\
7^{\circ} .- \\
8^{\circ} .- \\
9^{\circ} .-\end{array}$ \\
\hline
\end{tabular}

Continua 
Continuação

\begin{tabular}{|c|c|c|c|c|c|c|}
\hline $\begin{array}{l}\text { Projeto } \\
\text { Araribá }\end{array}$ & $\begin{array}{l}6^{\circ} .1 \\
7^{\circ} .- \\
8^{\circ} .- \\
9^{\circ} .-\end{array}$ & $\begin{array}{l}6^{\circ} .2 \\
7^{\circ} .- \\
8^{\circ} .- \\
9^{\circ} .-\end{array}$ & $\begin{array}{l}6^{\circ} .- \\
7^{\circ} .- \\
8^{\circ} .- \\
9^{\circ} .-\end{array}$ & $\begin{array}{l}6^{\circ} .1 \\
7^{\circ} .1 \\
8^{\circ} .2 \\
9^{\circ} .3\end{array}$ & $\begin{array}{l}6^{\circ} .2 \\
7^{\circ} .- \\
8^{\circ} .1 \\
9^{\circ} .-\end{array}$ & $\begin{array}{l}6^{\circ} .1 \\
7^{\circ} .- \\
8^{\circ} .1 \\
9^{\circ} .-\end{array}$ \\
\hline $\begin{array}{l}\text { Projeto } \\
\text { Radix }\end{array}$ & $\begin{array}{l}6^{\circ} .1 \\
7^{\circ} .- \\
8^{\circ} .1 \\
9^{\circ} .-\end{array}$ & $\begin{array}{l}6^{\circ} .2 \\
7^{\circ} .- \\
8^{\circ} .- \\
9^{\circ} .-\end{array}$ & $\begin{array}{l}6^{\circ} .- \\
7^{\circ} .- \\
8^{\circ} .- \\
9^{\circ} .-\end{array}$ & $\begin{array}{l}6^{\circ} .1 \\
7^{\circ} .- \\
8^{\circ} .1 \\
9^{\circ} .-\end{array}$ & $\begin{array}{l}6^{\circ} .- \\
7^{\mathrm{o}} .- \\
8^{\circ} .- \\
9^{\circ} .-\end{array}$ & $\begin{array}{l}6^{\circ} .2 \\
7^{\circ} .- \\
8^{\circ} .- \\
9^{\circ} .-\end{array}$ \\
\hline $\begin{array}{l}\text { Saber e fazer } \\
\text { História }\end{array}$ & $\begin{array}{l}6^{\circ} .1 \\
7^{\mathrm{o}} .- \\
8^{\circ} .- \\
9^{\circ} .-\end{array}$ & $\begin{array}{l}6^{\circ} .2 \\
7^{\circ} .- \\
8^{\circ} .- \\
9^{\circ} .-\end{array}$ & $\begin{array}{l}6^{\circ} .- \\
7^{\circ} .- \\
8^{\circ} .- \\
9^{\circ} .-\end{array}$ & $\begin{array}{l}6^{\circ} .4 \\
7^{\circ} .1 \\
8^{\circ} .- \\
9^{\circ} .-\end{array}$ & $\begin{array}{l}6^{\circ} .2 \\
7^{\mathrm{o}} .1 \\
8^{\circ} .- \\
9^{\circ} .-\end{array}$ & $\begin{array}{l}6^{\circ} .1 \\
7^{\circ} .- \\
8^{\circ} .- \\
9^{\circ} .-\end{array}$ \\
\hline $\begin{array}{l}\text { Tudo é } \\
\text { História }\end{array}$ & $\begin{array}{l}6^{\circ} .- \\
7^{\circ} .- \\
8^{\circ} .- \\
9^{\circ} .-\end{array}$ & $\begin{array}{l}6^{\circ} .- \\
7^{\circ} .- \\
8^{\circ} .- \\
9^{\circ} .-\end{array}$ & $\begin{array}{l}6^{\circ} .- \\
7^{\circ} .- \\
8^{\circ} .- \\
9^{\circ} .-\end{array}$ & $\begin{array}{l}6^{\circ} .1 \\
7^{\circ} .- \\
8^{\circ} .- \\
9^{\circ} .-\end{array}$ & $\begin{array}{l}6^{\circ} .- \\
7^{\circ} .- \\
8^{\circ} .- \\
9^{\circ} .-\end{array}$ & $\begin{array}{l}6^{\circ} .- \\
7^{\circ} .- \\
8^{\circ} .- \\
9^{\circ} .-\end{array}$ \\
\hline $\begin{array}{l}\text { Vontade de } \\
\text { saber }\end{array}$ & $\begin{array}{l}6^{\circ} .2 \\
7^{\circ} .1 \\
8^{\circ} .1 \\
9^{\circ} .1\end{array}$ & $\begin{array}{l}6^{\circ} .4 \\
7^{\circ} .5 \\
8^{\circ} .4 \\
9^{\circ} .3\end{array}$ & $\begin{array}{l}6^{\circ} .- \\
7^{\circ} .- \\
8^{\circ} .- \\
9^{\circ} .-\end{array}$ & $\begin{array}{l}6^{\circ} .1 \\
7^{\circ} .- \\
8^{\circ} .- \\
9^{\circ} .-\end{array}$ & $\begin{array}{l}6^{\circ} .- \\
7^{\mathrm{o}} .- \\
8^{\mathrm{o}} .- \\
9^{\circ} .1\end{array}$ & $\begin{array}{l}6^{\circ} .1 \\
7^{\circ} .- \\
8^{\circ} .- \\
9^{\circ} .-\end{array}$ \\
\hline
\end{tabular}

O gráfico abaixo revela a proporção com que tal dimensão conceitual aparece nas obras aprovadas:

\section{O conceito de História é tematizado nos livros didáticos de História?}

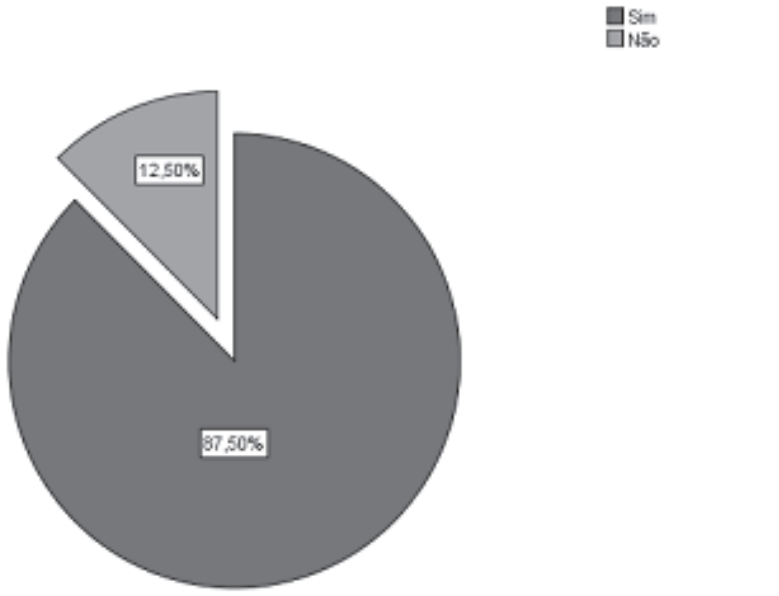

A disparidade entre as coleções que valorizam a dimensão conceitual como ponto de partida para a aprendizagem histórica e as que não discutem o conceito é notória. Isso nos leva a afirmar que, hoje, é uma tendência, entre as coleções, introduzir uma discussão do campo, mesmo que a tônica procedimental não seja 
característica principal da obra. Essa atenção maior dos autores em relação à discussão do campo tem a ver com as próprias inovações historiográficas e o crescimento das discussões em torno do ensino de História.

Enfim, o debate conceitual do campo historiográfico, embora seja uma tendência nas coleções, não significa dizer que naturalmente o procedimento ocupará lugar de destaque na obra. Como se observa no quadro de frequências, há, na maior parte das coleções, uma fragmentação na perspectiva formativa em relação à História, visto que, quando a discussão procedimental do campo aparece, não estabelece continuidade nos demais anos de escolarização, não aprofundando as especificidades do campo quanto à variação de pontos de vista, à inferência a partir dos documentos, à seleção das fontes, às intencionalidades de recortes e, possivelmente, as práticas de Memórias também serão deixadas à margem. Isso traz implicações importantes para se refletir a dimensão de aprendizagem, muitas vezes, subjacente à obra, considerando-se que conceitos centrais à compreensão do procedimento são lançados em um momento inicial do processo de escolarização e jamais retomados, como se processos de aprendizagem pudessem ser reduzidos a um momento delimitado e pontual.

Em relação à discussão conceitual da Memória, que é uma dimensão fundamental para a formação do saber histórico escolar, na medida em que permite o estabelecimento de conexões com aquilo que diz respeito ao universo de significados próprio dos estudantes, o gráfico revela outras proporções, bem menos animadoras, como exposto abaixo:

\section{O canceito de Memória é tematizado nos liyros dićáticos de História?}

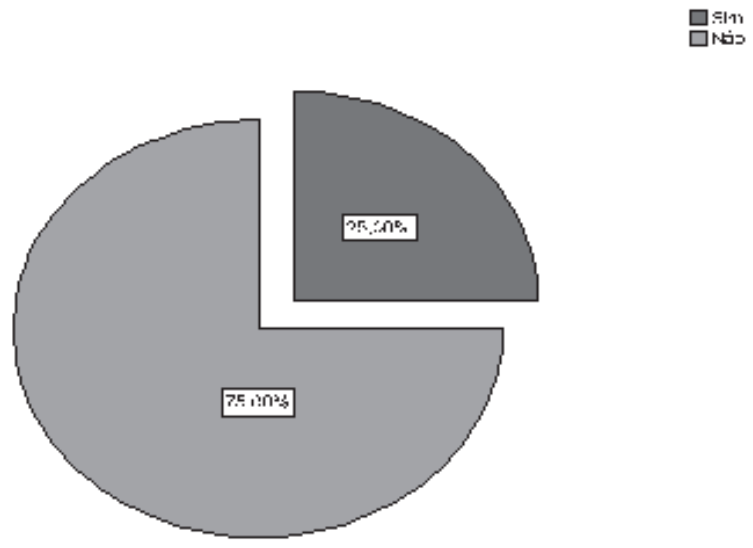


A partir dessa representação, pode-se dizer que salta aos olhos a ausência significativa da discussão do conceito de Memória em boa parte das coleções aprovadas em 2011. Embora o cenário de positivação da discussão conceitual da Memória seja pequeno em relação ao universo de coleções analisadas, pode-se considerar que houve um grande avanço dessa discussão dentro do ensino de História, uma vez que, até décadas atrás, esse quadro reflexivo era quase ausente nos livros didáticos. Esse movimento de interesse recente pela discussão da Memória tem razões vinculadas, como já foi dito, à própria dinâmica da contemporaneidade que nos faz, hoje, valorizar a Memória como elo sensível de construção de sentido, tanto de passado quanto de futuro. E, de maneira especial, às inovações no campo historiográfico, em que pese a força do campo da História Cultural, que ampliaram nosso olhar para a riqueza presente nas representações.

É importante ressaltar que consideramos, neste quadro, a dimensão conceitual explícita do campo da Memória. Isso não significa dizer que $25 \%$ das coleções estabelecem relação de diálogo entre História e Memória e nem que os $75 \%$ ignoram essa relação por não trazerem o conceito. Seria por demais arriscado classificar as coleções levando somente em consideração a reflexão conceitual. Para isso, buscamos, num segundo movimento, fazer uma análise mais abrangente das coleções. Para tanto, foram considerados possíveis cenários de diálogo entre História e Memória, sem que o recorte recaísse apenas na conceituação dos campos, mas, sobretudo, na relação estabelecida entre eles. Dentro dessa possibilidade, verifica-se um cenário particular, representado pelo gráfico a seguir.

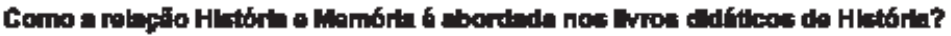
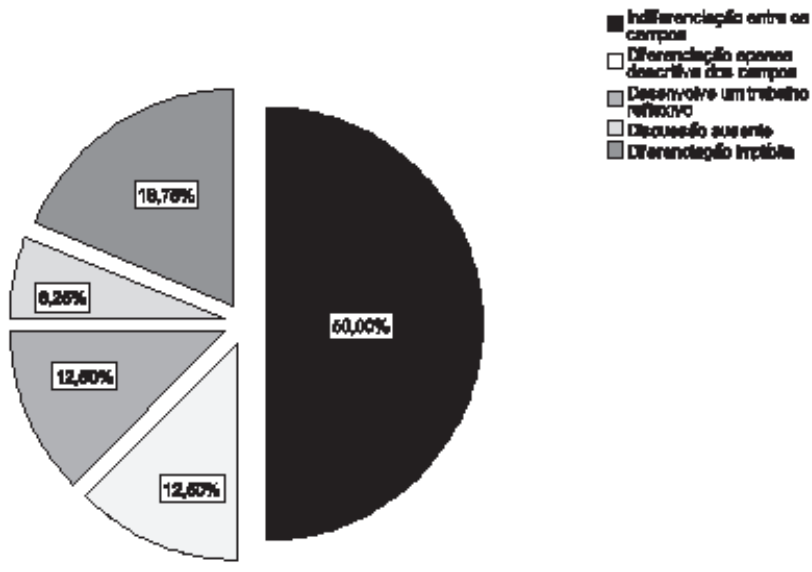
Ainda ampliando o leque de possibilidades possíveis de diálogos entre os campos, é possível perceber que em 6,25\% das coleções é ignorada, por completo, a relação História e Memória. Nessa porção não há nenhuma evidência ou possibilidade de intenção do(s) autor(es) em discutir a Memória na relação com o saber histórico escolar. Por outro lado, fica evidente que 50\% das coleções, que possivelmente buscam essa relação, não conseguem tratar os campos como complementares e distintos, mas sim como sinônimos. Essa "indiferenciação entre os campos", presente na maior parte das coleções, resulta de um olhar específico dos seus autores sobre o campo da História e do que consideram importante para a ação de educação histórica. Não por mera coincidência, o perfil dessas coleções, dentro do quadro avaliativo do MEC, consiste num caráter "informativo" no que se refere às estratégias didáticas e à sua construção textual. Ou seja, essas obras possuem uma abordagem mais tradicional, na qual o procedimento não ocupa lugar central em suas perspectivas didáticas.

Outro grupo de coleções opta por uma abordagem apenas descritiva quanto à diferenciação entre os campos, ou seja, 12,50\% das obras entendem a distinção entre História e Memória, mas não desenvolvem, ao longo da coleção, uma reflexão mais aprofundada ou propõem atividades didáticas capazes de mobilizar o tratamento procedimental dos campos.

Observando o quadro de frequência, é possível perceber uma tendência predominante, no conjunto das coleções, de restringir a discussão conceitual dos campos da História, e quando muito da Memória, ao $6^{\circ}$ ano escolar. Nesse sentido, as coleções revelam fragilidades quanto aos processos didáticos de construção conceitual. É como se o fato de o tema ter sido abordado em um ano de escolarização garantisse a construção cognitiva efetiva, o que, sabemos, não se verifica na prática, dada a complexidade inerente a tal dimensão conceitual. Dessa forma, a aprendizagem deixa de ser vista de maneira processual, cuja formação pressupõe retrocessos, repetições e aprofundamentos em termos de complexidade.

Outro grupo de coleções apresentou um perfil de fronteira entre a diferenciação ou não dos campos. Em 18,75\% das coleções, o tema da Memória não é discutido conceitualmente, mas a obra lança mão de estratégias que evidenciam uma intenção de tratamento do campo. Essas obras receberam a denominação de "diferenciação implícita", por se tratar de coleções em que a vontade do autor não se revelou, nitidamente, numa primeira leitura, mas que, num segundo momento, em atividades, legendas, imagens ou textos complementares, a dimensão da Memória foi abordada na relação com o campo do historiador.

Claro que em coleções como essas, cuja classificação é tênue, foi necessário olhar mais detidamente os manuais didáticos destinados aos professores para 
tentar perceber se a discussão da Memória na relação com o ensino de História se constituía como campo de interesse específico. Enfim, esses grupos que trazem, implicitamente, o diálogo com as operações de Memória são heterogêneos. Na grande maioria dos casos, a discussão da Memória consta na bibliografia, mas suas orientações são pouco elucidativas, o que dificulta ainda mais precisar a intenção do autor no que se refere à importância dada à discussão da Memória.

Vale lembrar que o Manual do Professor, a partir do PNLD 2011, tornou-se critério de exclusão para uma obra, o que, de certa maneira, obrigou os autores a produzir com maior cuidado esse material pedagógico. Considerando que os autores revelam seus pressupostos acadêmicos, suas escolhas quanto ao tipo de abordagem e a estratégia didática adotada no diálogo com os professores, sobretudo para os orientarem em suas atividades e formação, o Manual tornou-se, também, objeto de reflexão nesta pesquisa, para entender como esses autores discutem os campos da História e da Memória.

Em um primeiro olhar sobre os manuais, buscamos localizar a possibilidade de orientação pedagógica quanto à discussão dos campos e, nesse movimento inicial em relação aos manuais, foi possível constatar que, em 50\% dos casos, a relação História e Memória é tematizada nos manuais do professor.

\section{A relação História e Memória é tematizada nos manuais do professor?}
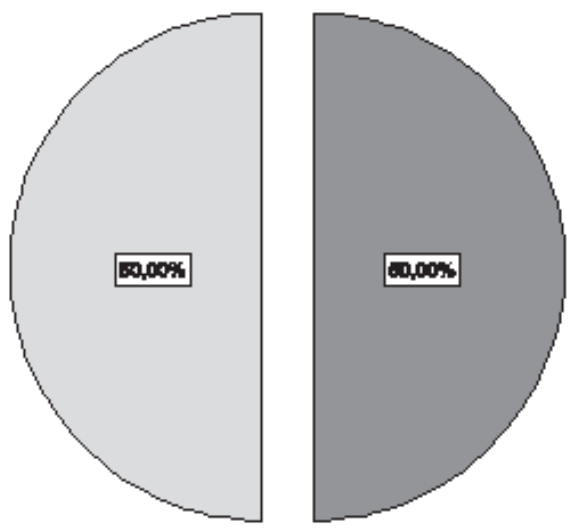

Ou seja, de acordo com o gráfico acima, a temática da Memória na relação com o campo historiográfico aparece com maior frequência nos manuais que nos livros didáticos destinados aos alunos. Isso não significa dizer que, dentre esses $50 \%$ que discutem a relação entre os campos, todos o fazem de forma aprofun- 
dada. Esse passou a ser, então, o segundo movimento: perceber, nos manuais que trabalham a relação Memória e História, a forma de tratamento dispensada pelo autor. A construção da orientação didática diz muito da perspectiva da obra e do autor; afinal, ela serve como suporte didático para maiores esclarecimentos ao professor sobre a natureza da discussão apresentada no livro do aluno.

Para isso, buscamos uma classificação semelhante à apresentada pelo Guia de Livros Didáticos de 2011 do MEC, ou seja, os manuais foram classificados em "formal", "reflexivo" e, naqueles onde a discussão não acontecia, "discussão ausente". Sob esses critérios, obtivemos o gráfico seguinte:

\section{Como a relagio Historla * Memorla \& abordada nos manuals do professor?}
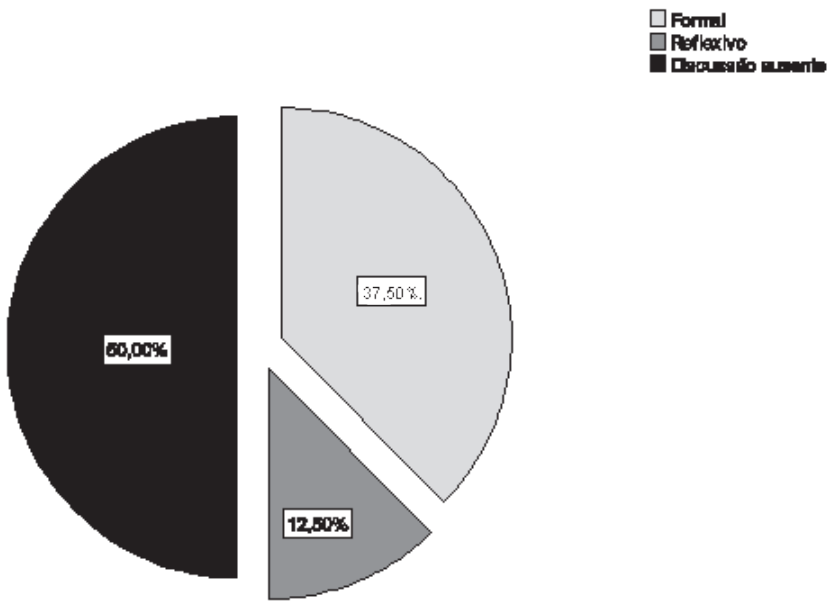

Com esse levantamento, tem-se que a maior parte dos manuais que discutem a relação entre os campos o faz de maneira "formal". Desse modo, a coleção cai numa narrativa explicativa sobre os campos, com poucas problematizações e/ou pistas didáticas que orientem o professor a explorar, com potencialidade, a temática. Dentro desse universo "formal", encontram-se manuais que citam o trabalho com fontes orais como instrumento didático para formação histórica, mas não nutrem o professor com reflexões didáticas acerca da potência que esse tipo de atividade possui.

A ausência de discussão da relação entre História e Memória, identificada em $50 \%$ dos manuais, deriva, essencialmente, do fato de que essa distinção não se projeta, para grande parte dos autores dos livros didáticos, como uma questão atinente ao campo do ensino de História que, em geral, é pensado somente do ponto de vista da construção de narrativas de exemplaridade do 
passado ou a partir da valorização de conteúdos históricos, independentemente de seus sentidos e dos processos de mediação pedagógica. Como Circe Bittencourt considera, o saber histórico escolar "não pode ser entendido como mera e simples transposição de um conhecimento maior, proveniente da ciência de referência e que é vulgarizado pelo ensino." (1997, p. 25). Mais que saberes de erudição, o saber histórico escolar constitui-se também de multiplicidades de vozes cheias de valores, crenças, pontos de vista, práticas, conflitos e, por que não dizer, silêncios que estão postos numa sala de aula.

$\mathrm{O}$ que se pode observar, olhando para os gráficos em conjunto e para o quadro de referência, é que a temática da Memória é um campo a ser explorado dentro do ensino de História, sobretudo nas coleções que, em sua maioria, olham para os campos da Memória e da História de maneira indiferenciada. Se adotarmos que a História, enquanto campo de saber, é, por pressuposto, composta de debate, divergências, variação de pontos de vista, crítica e diálogo com as fontes, e não espelho fiel do passado, devemos abrir, para uma efetiva formação histórica dos nossos alunos, o universo de potencialidades que o campo possui, sobretudo no que se refere ao procedimento histórico que interfere diretamente na construção do conhecimento. E, nesse lugar, as operações de Memória estão fortemente arraigadas e não devem ser objeto de descuido ou ausência de problematização.

\section{Considerações finais}

A partir de um olhar panorâmico sobre as obras, pode-se afirmar que a maior parte das coleções trata os campos da Memória e da História como unidades conceituais indiferenciadas, o que implica dizer que os autores, muitas vezes, não dimensionam o lugar de cada campo enquanto operações distintas, porém igualmente importantes, complementares e necessárias ao processo de formação do pensamento histórico. A ausência dessa reflexão no ensino de História reduz as condições efetivas de reflexividade docente, na medida em que o empoderamento que se dá pela via da construção teórica dos campos da Memória e da História não ocorre a partir daquilo que se apresenta na obra e nas orientações propostas ao professor, ainda que muitas construções possam ser engendradas pelo docente, no repertório de usos que vai construindo para o livro didático em sua prática cotidiana.

O processo de educação para compreensão da História se fortalece na medida em que o procedimento se constitui como ponto de partida para formação do pensamento histórico do aluno. Ivo Mattozzi considera 
[...] se concebemos a História como matéria (complexo de noções cristalizadas em manuais), não há lugar para a Memória na escola senão com a função de decorar datas, nomes, fatos, conceitos... Para poder admitir a Memória como objeto de atenção didática nos processos de ensino e de compreensão, é necessário conceber a História como disciplina, isto é, incluir também o método, e, além dos conhecimentos e dos procedimentos do trabalho historiográfico, as operações cognitivas e práticas que o fazem possível. (2008, p. 13).

Nesse sentido, as especificidades das operações de Memória como o lembrar e o esquecer, o ato de arquivar a própria vida, a compreensão da dimensão fragmentária da lembrança a partir do esquecimento - assim como as seleções e as intencionalidades que permeiam tais preservações -, os silêncios e silenciamentos experienciados ao longo de nossa existência encontram relevância junto ao saber histórico escolar, pois dizem de saberes que se constituem como plano de referência de mundo do aluno e que podem ser postos em diálogo com outros tempos.

Pensar as relações de (in)visibilidade quanto às distinções epistemológicas entre História e Memória nos livros didáticos de História é fundamental para a reflexão do saber histórico escolar, na medida em que, muitas vezes, esse campo de saber é dimensionado como lugar de aquisição de uma dada interpretação do passado tomada como produção histórica unívoca. Nessa perspectiva, o ensino de História se restringe à relativização inerente às operações de Memória, ação comum, sobretudo na educação dos anos iniciais, quando a Memória não se converte em interpretação histórica pautada na construção da historicidade. Além disso, é muito comum, também nos anos iniciais, se observar a presença dos elementos da Memória sem que em torno deles seja provocada, didaticamente, uma reflexão acerca da dimensão social e não meramente subjetiva dessas práticas. Isso significa dizer que um objeto de criança não nos permite, em sala de aula, restituir a história daquela criança, mas nos permite conduzi-la a compreender que aquele objeto resulta de uma operação de seleção, uma escolha de lembrança em meio a muitas escolhas de esquecimento e destruição. Permite-nos também auxiliá-la a compreender que há algo que se repete em meio às histórias individuais em uma determinada geração e que, se compararmos várias gerações, nos passa a ser possível capturar continuidades e descontinuidades temporais, mudanças e permanências na passagem do tempo.

Embora se tenha constatado que a maior parte das produções didáticas de História esteja assentada no mimetismo entre os campos, é possível perceber que há coleções que procuram dar visibilidade à discussão das operações de 
Memória como elemento ativador para a formação histórica. Tais coleções buscam valorizar a Memória como procedimento capaz de projetar novas maneiras de narrar o passado através de um processo de construção de sentido, diferente de uma transmissão vertical que negligencia os saberes trazidos pelos alunos. Vale ressaltar que o fato de algumas coleções tirarem a Memória do plano de invisibilidade não significa dizer que elas não possuam fragilidades e limites a serem enfrentados pelos autores. Porém, quando a Memória é mobilizada como âncora para a formação histórica, ela se constitui como plano de possibilidade para lidar com a projeção, para cada aluno, que sua história e sua cotidianidade estão inseridas em um plano social maior. Essa reflexão didática possui consequências fundamentais na forma com que o aluno passa a ler o mundo, pois ele, enquanto sujeito do conhecimento, passa a poder se enxergar como sujeito da História, na medida em que sua Memória e sua constituição identitária conversam com outras realidades em outros tempos e espaços.

Por esse motivo, consideramos que ainda há muito a ser discutido em termos de realidade conceitual na produção de livros didáticos de História no Brasil. Por meio da análise detida sobre o conjunto das obras didáticas aprovadas no PNLD 2011, foi possível constatar que ainda há o predomínio de uma perspectiva de História totalizante e integrada, pautada em uma visão mais informativa que procedimental. Em outras palavras, verifica-se uma preocupação maior com a erudição dos fatos históricos do que com a formação do pensamento histórico que gere uma atitude intelectual do aluno diante do mundo. Pode-se considerar, a partir desse perfil predominante nos livros didáticos de História, que esse é um desafio a mais de reflexão que se projeta para editoras, para autores e, especialmente, para os professores.

Há algum tempo Ecléa Bosi nos alertou para o fato de que "as instituições escolares reproduzem essas versões [produzidas pela Memória de uma classe dominante] solidificando uma certa memória social e operando em sentido inverso ao da lembrança pessoal, tão mais veraz em suas hesitações, lacunas e perplexidades" (2003, p. 23). Acreditamos na potência formativa da Memória enquanto mecanismo capaz de permitir à criança, ao jovem, ao adulto, conscientizar-se de seu lugar no mundo e na história, por meio da ativação de sentidos e sensibilidades naquilo que lhe constitui como pessoa e nos rastros constituídos em sua própria vida. Portanto, a Memória na escola abre-se como uma porta capaz de promover bases de identificação com um passado que soa ao estudante, muitas vezes, como algo abstrato e distante, intangível. Tomar consciência dessa distinção - e, portanto, torná-la visível - pode vir a se constituir ferramenta conceitual com força de empoderamento do professor. Desse modo, a formação histórica capaz de lançar mão do procedimento histórico em sua dimensão formativa, sem abdicar da centralidade passível de ser ocupada 
pelas operações de memória, pode fortalecer, em qualquer pessoa, a capacidade de historicizar a própria vida, reencontrar as utopias partilhadas nas lembranças comuns e, assim, reencontrar sentidos outros para o estudo da História.

\section{REFERÊNCIAS}

ALMEIDA, Fabiana Rodrigues. História e memória nos limites do (in)visivel: reflexões do saber histórico escolar nos livros didáticos de história. Dissertação (Mestrado) - Programa de Pós-Graduação em Educação, Universidade Federal de Juiz de Fora, 2012.

BENJAMIN, Walter. A obra de arte na era da reprodutibilidade técnica. In: Obras escolhidas. São Paulo: Brasiliense, 1987.

BITTENCOURT, Circe. O saber histórico em sala de aula. São Paulo: Contexto, 1997. BOSI, Ecléa. O tempo vivo da Memória. São Paulo: Ateliê Editorial, 2003.

BURKE, Peter. História como memória social. In: . Variedades de história cultural. Rio de Janeiro: Civilização Brasileira, 2000.

CUESTA-FERNANDES, Raimundo. Clio en las aulas: la enseñanza de la historia en España. Entre reformas, ilusiones y rutinas. Madri: Ediciones Akal, 1998.

GOODSON, Ivor. Currículo, narrativa e futuro social. Revista Brasileira de Educação v. 12 n. 35 maio/ago. 2007

GUIA DE LIVROS DIDÁTICOS: PNLD 2011. História. - Brasília: Ministério da Educação, Secretaria de Educação Básica, 2010.

GUIMARÃES, Manuel Luiz Salgado. Escrita da história e ensino da história: tensões e paradoxos. In: ROCHA, Helenice et al. A escrita da história escolar: memória e historiografia. Rio de Janeiro: Ed. FGV, 2009.

HUYSSEN, Andreas. Seduzidos pela memória. Rio de Janeiro: Aeroplano, 2000. 2008. et al. Heterocronias: tempo, arte y arqueologias del presente. Murcia: Cendeac, . La hantisse de l'oubli: essais sur les résurgences du passé. Bruxeles: Kimé, 2011. JEDLOWSKI, Paolo. Memoria. Bologna: CLUEB e Museo Morandi, 2000. . Memoria, esperienza e modernità: memoria e società nel XX secolo. Milano: Franco Angeli, 2002. . Il sapere della esperienza: fra l'abitudine e il dubbio. Roma: Carocci, 2010. 
KOSELLECK, Renhardt. Los estratos del tiempo: estudios sobre la historia. Barcelona: Paidós, 2001.

MATTOZZI, Ivo. Memória e formação histórica: a memória na aula de História. In: RAMOS, F. R. L.; LUCAS, M. R. L. Tempo no plural. Fortaleza: Realce, 2008.

MIRANDA, Sonia Regina. Sob o signo da memória. Cultura escolar, saberes docentes e história ensinada. São Paulo: Editora UNESP; Juiz de Fora: Ed. UFJF, 2007.

. Práticas de memória e educação da sensibilidade histórica: horizontes teóricos em uma zona de fronteira. In: YAZBECK, D. C. de M.; SARMENTO, D. C. Escola e sistema de ensino: memória, gestão e saberes. Juiz de Fora: Ed. UFJF, 2009.

NORA, Pierre. Entre memória e história: a problemática dos lugares. Revista Projeto História, São Paulo: PUC, 1993.

. Lieux de memoire. Paris: Gallimard, 1997.

ORWELL, George. 1984. 12. ed. Rio de Janeiro: Nacional, 1979.

RICOEUR, Paul. A memória, a história, o esquecimento. Campinas: Ed. Unicamp, 2008.

SARLO, Beatriz. Tiempo pasado: cultura de la memoria y giro subjetivo, una discussion. Buenos Aires: Siglo XXI, 2005a.

Tempo presente: notas sobre a mudança de uma cultura. Rio de Janeiro: José Olympio, 2005b.

. La ciudad vista, mercancías y cultura urbana. Buenos Aires: Siglo XXI, 2009.

SILVA, Sônia Maria Meneses. Sob o fardo do presente: mídia, memória e esquecimento questões para pensar a história na contemporaneidade. Dossiê História e Memória, v. 6, n. 7, julho/2009.

\section{Referências das coleções didáticas analisadas}

APOLINÁRIO, Maria Raquel. História 6: Projeto Araribá. v. $6^{\circ}, 7^{\circ}, 8^{\circ}, 9^{\circ}$ ano. São Paulo: Moderna, 2007.

BOULOS JÚNIOR, Alfredo. História: sociedade e cidadania. v. $6^{\circ}, 7^{\circ}, 8^{\circ}, 9^{\circ}$ ano. São Paulo: FTD, 2009.

BRAICK, Patrícia Ramos; MOTA, Myriam Becho. História das cavernas ao terceiro milênio. v. $6^{\circ}, 7^{\circ}, 8^{\circ}, 9^{\circ}$ ano. São Paulo: Moderna, 2009.

CABRINI, Conceição. História temática: o mundo dos cidadãos. v. $6^{\circ}, 7^{\circ}, 8^{\circ}, 9^{\circ}$ ano. São Paulo: Scipione, 2009.

CARDOSO, Oldimar Pontes. Tudo é história. v. $6^{\circ}, 7^{\circ}, 8^{\circ}, 9^{\circ}$ ano. São Paulo: Ática, 2009. COTRIM, Gilberto. Saber e fazer história. v. $6^{\circ}, 7^{\circ}, 8^{\circ}, 9^{\circ}$ ano. São Paulo: Saraiva, 2009. 
DOMINGUES, J. E. História em documento: imagem e texto. v. $6^{\circ}, 7^{\circ}, 8^{\circ}, 9^{\circ}$ ano. São Paulo: FTD, 2009.

DREGUER, Ricardo; TOLEDO, Eliete. Nova História: conceitos e procedimentos. v. $6^{\circ}, 7^{\circ}, 8^{\circ}, 9^{\circ}$ ano. São Paulo: Atual, 2009.

FIGUEIRA, Divalte Garcia; VARGAS, João Tristan. Para entender História. v. $6^{\circ}, 7^{\circ}$, $8^{\circ}, 9^{\circ}$ ano. São Paulo: Saraiva, 2009.

MELO, Leonel Itassu de Almeida; COSTA, Luis César. História. v. $6^{\circ}, 7^{\circ}, 8^{\circ}, 9^{\circ}$ ano. São Paulo: Scipione, 2009.

MOTOOKA, Débora Yumi. Para viver juntos: História. v. $6^{\circ}, 7^{\circ}, 8^{\circ}, 9^{\circ}$ ano. São Paulo: Edições SM, 2009.

OLIVEIRA, Maria da Conceição Carneiro de. História em projetos. v. $6^{\circ}, 7^{\circ}, 8^{\circ}, 9^{\circ}$ ano. São Paulo: Ática, 2009.

PELLEGRINI, Marco César. Vontade de saber história. v. $6^{\circ}, 7^{\circ}, 8^{\circ}, 9^{\circ}$ ano. São Paulo: FTD, 2009.

PILETTI, Nelson. História e vida integrada. v. $6^{\circ}, 7^{\circ}, 8^{\circ}, 9^{\circ}$ ano. São Paulo: Ática, 2009.

VAZ, Maria Luísa; PANAZZO, Silvia. Navegando pela História. v. $6^{\circ}, 7^{\circ}, 8^{\circ}, 9^{\circ}$ ano, nova ed. São Paulo: FTD, 2009.

VICENTINO, Cláudio. História: Projeto Radix. v. $6^{\circ}, 7^{\circ}, 8^{\circ}, 9^{\circ}$ ano. São Paulo: Scipione, 2009.

Texto recebido em 28 de setembro de 2012.

Texto aprovado em 19 de novembro de 2012. 